

RETORIKA: Jurnal Ilmu Bahasa

Vol. 5, No. 1 April 2019, Page 45-51

\title{
Possessive Construction in Uab Meto
}

P-ISSN: 2406-9019

E-ISSN: 2443-0668

Available Online at https://ejournal.warmadewa.ac.id/index.php/jret

\author{
Naniana N Benu \\ Artha Wacana Christian University \\ nanibenu@ukaw.ac.id
}

\begin{tabular}{|l|}
\hline Received: 12/02/2018 Revised: 30/01/2019 \\
\hline How to cite (in APA style): \\
$\begin{array}{l}\text { Benu, N, N. (2019). Possessive Construction in Uab Meto. RETORIKA: Jurnal Ilmu Bahasa, 5(1), 45-51. doi: http:// } \\
\text { dx.doi.org/10.22225/jr.5.1.897.45-51 }\end{array}$ \\
\hline
\end{tabular}

\begin{abstract}
This paper is a result of research which is aimed to uncover the structure and marking on the possessive construction in Uab Meto based on morpho-syntax point of view. The data collected for this research were classified into the primary data (observation) and the secondary data (the data that are obtained from texts). The technique employed to analyze the data was descriptive-analytic, and the approach applied was deductive-inductive. The result of the research shows that in Uab Meto, predicative possession is expressed through the verb mui? 'have/has'. In some usages, mui? metathezised to mu?i. Possesive construction of Uab Meto is also applied topicalization strategy, and the last is using a verbal prefix ma-. This prefix ma- is a verbal prefix because it carries a verbal meaning, that is have/has. Furthermore, there are two attributive possessive constructions, namely juxtaposed construction. The possessor in juxtaposed constructions can be a noun or pronoun. The second attributive possessive is pronominal clitic to show the agreement with the possessors. Relating to the marking, there are only two ways, namely by juxtaposition and pertensive marker to mark the the possession. Uab Meto allows all pronouns to mark the attributive possessive relation. Without free pronoun as the possessor, a speaker Uab Meto will understand that it is a possessive noun phrase. Clitic in possession in is obligatory for inalienable possession in Uab Meto.
\end{abstract}

Keywords: Atributive; Morpho-Syntax; Possessive; Predicative; Uab Meto

\section{INTRODUCTION}

All languages have a way of expressing possession. Studies by many researchers in various languages show the different construction, either its types or its markings. Some Austronesian languages in East Nusa Tenggara had been investigated, such as Ende (McDonnell, 2008), Lamaholot (Nishiyama, 2009) and Waijewa (Ngongo, 2014). These research enriched the linguistic literatures, especially dealing with possessive construction.

This research discovered the morphosyntactic aspect of possessive construction in Uab Meto. This is an Austronesian language in west Timor, East Nusa Tenggara, which is also well known as Dawan language. The use of the term Uab Meto instead of Dawan in this paper is based on the reason that during the data collection, the informants who are also native speakers preferred to use the name Uab Meto for the language they speak.

The focus on possession in linguistic studies is based on the assumption that possession is a universal phenomenon, as stated by Heine (1997), that any human language can be expected to have a conventional way of expressing possession. Heine presented a review of the various definitions of possession that appear in the literature (Heine, 1997). For example, one of the concepts related to possession is 'control,' implying that there is some type of control of the possessor over the possessee. Another concept is related to 'sphere of influence and also 'schema of interest of involvement.

The term possession is a concept, not a construction that shows the relationship 
between a human being and his kinsman, his body part, his material belongings, his cultural and intellectual products (Wang \& Xu, 2013). To call the formal constructions of expressing possession as possessive constructions, even though the semantic relationship is not always one of possession, for instance, the phrase his teacher does not refer to a teacher that he "possess" in the same way that his clothes refers to clothes that he possess (Payne, 1997).

Payne (1997) classified possession semantically into alienable, inalienable and inherent. Alienable possessions are those with whom it is possible to in some way sever or terminate the relationship of possession (e.g. through loss, sale, or theft) (Payne, 1997). In contrast, inalienable possessions are inherently and permanently possessed. In cases of inalienable possession, of which kinship relations and body parts are prototypical examples, the possessed item is physically and/ or conceptually inseparable from the possessor. Inalienable possession is similar but not identical with inherent possession. As explained by Payne that certain items are inherently possessed, e.g., body parts, kinship terms, and items of personal adornment. Other items are not normally possessed, such as trees, the sky, etc.

Finally, in talking about possession, it may be best to start with a broad and general definition of possession: a possessive relationship holds between the possessum (an item or entity that is possessed) and the possessor (the person or entity which possesses the item). In addition, Payne explained that structurally, the possessor is the dependent, which modifies the possessum, the head of the construction (Payne, 1997).

Dixon (2005) mentioned five functions of possessive form, they are 1) an alienable possession, something that the possessor have. For example: John's car, Mary's ring, my dog, 2) a kin relation. For example: my mother, Mary's husband, 3) an inalienable part of the possessor. For example: John's foot, the tree's blossom, my name, 4) an attribute of the possessor. For example: Mary's age, your jealousy, John's good character, Bill's idea, and 5) something typically associated with the possessor. For example: Mary's hometown, my dentist, your boss (Dixon, 2005).

The Structure of Possessive Construction and Some Previous Researches

Syntactically, possessive construction in all languages are divided into predicative (or verbal) and attributive (or nominal) possession constructions (Heine, 1997; McDonnell, 2008). Heine argues that both predicative and attributive possession relating to the type of syntactic construction is that distinction has to be made within the domain of possession refers to whether the pos-sessum is conceived of as inalienable or alienable to the possessor.

In predicative possession constructions the possessor and possessum fill argument slots of the predicate. The linguistic expressions of having and belonging in English reflect the two main types of so-called predicative possession. English examples of the two types of predicative constructions are given in the following:

\section{I have a house.}

2. The house belongs to me.

It can be seen that the two constructions, i.e. the have-construction in (1) and the belongconstruction in (2), differ in a number of respects other than the choice of verb. These differences include the argument status of the possessor and posses-sum, the definiteness of the two nominal, and their information status within the clause. Have-constructions typically emphasize the possessor, as evidenced by the possessor's subject role in the clause and the indefiniteness of the possessum. In contrast, belong-constructions are typically characterized by a definite possessee in subject position, which places the emphasis on the possessum.

In contrast with predicative, attributive possession refers to constructions like my car or John's book, where syntax is nominal or phrasal. As the examples show, the relationship between the possessor and possessum is established within a noun phrase. Attributive possession is also called nominal or adnominal possession (Haspelmath, 2008). Moreover, these examples show a pronominal possessive relationship, where the possessor is a pronoun (e.g. $m y$ ), and a noun-noun relation-ship, where the possessor is a noun (e.g. John).

Structure, types, and marking of predicative or attributive construction in expressing the possession are varied in languages. In Ende, as investigated by MacDonnell (2008), there are at least two (and possibly three) predicative possessive constructions, namely a juxtaposed possessive construction and an existential possessive construction. Furthermore, there are three attributive possessive constructions; they are a juxtaposed possessive construction with pronouns, a juxtaposed possessive construction 
with possessive pronouns, and a ligature possessive construction (McDonnell, 2008).

The possessive predicates in Indonesian in order to describe how Indonesian encodes the 'possessive' notion in various types of possessive predicate construction (Moeljadi, 2010). He examined all factors contributing to the functional differentiation of the possessive predicates in constructions.

The results are: first, the register and the relation between the objects possessed and the '(in)alienability' notion play important roles in the encoding process, and secondly, he hypothesized that the enclitic =nya in the construction $X$ ada $Y=n y a$ functions as an 'inalienability marker' in the possessive construction with the existential verb ada and the 'inalienable' objects.

Nishiyama (2009) elaborated the possessive construction in Lamaholot. He said that Lamaholot is such a language, where 'teacher's house' is either guru lango-nvn 'teacher house-3sg' or lango guru na'en 'house teacher his'. Possessors are marked either by a genitive pronoun or a suffix, and they are in complementary distribution (Nishiyama, 2009).

There are four cases to consider, namely first, possessor is genitive pronoun, and the full NP possessor is absent. In this type, the possessed is followed by a genitive pronoun. For example oto mo'en 'your car' or mata go'en 'my eye'. Second, possessor is suffix, the full NP possessor is absent. In this type, a possessive suffix is attached to the possessed. For example, lango-ke 'your (pl) house' or bapa'-kvn 'my father'. Third, possessor is genitive pronoun, the full NP possessor is present. For example, lango guru na'en 'the teacher's house'. When the possessed noun is understood, the noun can be dropped and guru na'en itself can mean 'the teachers' (something).' If the possessor is plural, ra'en is used: lango guru ra'en 'the teachers' (pl) house(s)/faculty resident' their teacher house. Fourth, possessor is suffix, the full NP possessor is present. For example, guru oto- $n v n$ 'teacher's (sg) car' teacher car-3sg. The verbal suffix -na is strictly prohibited in possessive construction: *guru oto-na 'teacher car-3sg' is ungrammatical. The same distinction can be made by the genitive pronoun in the third type possessive construction as oto guru na'en 'teacher's (sg) car ' or oto guru ra'en 'teachers' (pl) car'.

The characteristics of possessive construction in Lamaholot investigated by
(Nishiyama, 2009) as is almost the same as Norwegian done (Lødrup, 2011). In Norwegian, it is found that structurally, possessor can be placed before or after the possession. For example, min bil 'my car' or bilen min 'car.DEF my'. The pronoun my placed before the possession, so it is called prenomonal and after is called postnominal.

The term pronominal and postnominal used by Lødrup is based on the standard assumption of the Principles and Parameters theory, which said that is possessive pronouns are prenominal in underlying structure, while the postnominal position is a result of $\mathrm{N}$ movement. However, Lødrup used Lexical Functional Grammar for the analysis, which focused on the grammatical differences between the positions. Lødrup argued that they motivate an analysis in which prenominal and postnominal possessive pronouns do not realize one underlying position. According to Lødrup, Lexical Functional Grammar makes it possible to implement this kind of analysis in a simple way (Lødrup, 2011). The basic properties of prenominal and postnominal possessive pronouns follow from the theory of strong and weak pronouns. There is evidence, however, that the dialect of Western Oslo has a group of suffixal possessives.

\section{Marking on the possessive construction}

Relating to the morphological marking on the possessive construction, (Tallerman, 2011) stated three types of marking in possessive construction, namely dependent marking, head marking and double marking. There are five formal ways of possessive NP marking as follows (Aikhenvald, 2013):

1. Order of words within an NP constituent. Marking possession involves simple juxtaposition. Possessor can precede the Possessee, as in Tucano (Aikhenvald, 2013) and Ende (McDonnell, 2008).

2. Marking on possessor this is typically achieved with the so called 'genitive' case, as in English (Dixon, 2005), German (Aikhenvald, 2013) and Waijewa (Ngongo, 2014).

3. Marking on possessee. This can be achieved with the 'pertensive' marker. The term 'pertensive' is based on the Latin verb pertinēre 'belong' and straightforwardly relates to the function of the marker: it shows that the referent 'belongs' to something or someone (Dixon, 2010).

4. Marking on both, as in Turkish (Aikhenvald, 2013). 
5. Using an independent marker. As in Mandarin (Aikhenvald, 2013).

\section{METHOD}

This research attempts to describe the linguistic phenomenon in Uab Meto especially those that are concerned with possessive construction. The data collected for this research were classified into the primary data, namely observation and interview and the secondary data which obtained from texts. The technique employed to analyze the data was descriptive-analytic, and the approach applied was deductive-inductive.

\section{RESULT AND DISCUSSION}

The structure of possessive construction in Uab Meto is syntactically divided into predicative and attributive. Predicative possession is so-called because it is predicative or verbal in nature, that is, predicative possession constructions have clausal syntax, whereby the possessor and possession fill argument slots of the predicate.

In Uab Meto, predicate of a clause is not always a verb. In other words, there is verbal and nonverbal predicate in a clause. So, predicative possession in Uab Meto to be discussed here is including verbal and verbless predicate.

Attributive possession refers to constructions like my house or Nani's book, where its syntax is nominal or phrasal. As the examples show, the relationship between the possessor and possession is established within a noun phrase. This is the reason why it is also called nominal or adnominal possession.

\section{Predicative Possession}

Predicative possession discussed in this paper is clausal in syntax. It means that the expression is in form of clause. There are three different constructions in predicative possession in Uab Meto, namely verbal predicative mui?, topicalization, and verbal prefix $m a-$.

\section{Verbal predicate}

Verbal predicative possession in Uab Meto is represented by verb mui? "have/has". In some usages, it sometimes metathezised to $m u$ ? $i$. This verb is considered as a transitive verb which takes two arguments in a clause, namely possessor in A function and possession in $\mathrm{O}$ function. This verb, like other verbs in Uab Meto, is always agreed with subject, which is indicated by proclitic on the verb.
Data bellow will show the construction clearly.

1). Na Nani n-mui? ume

ART NAME 3Sg-has house

Nani has hause'

In the example (1), the verb is marked by the proclitic $n$ - which refers to the $3 \mathrm{Sg}$ subject. $\mathrm{Na}$ Nani and ume 'hause' are the arguments of the verb. The examination on the use of the predicate mui? proved that it is only used for alienable possession, but never to inalienable possession such as body part.

2) a. Au ?-mui? ume

$1 \mathrm{Sg} 1 \mathrm{Sg}$-have house 'I have house'

b. **au P-mui?hae

$1 \mathrm{Sg} 1 \mathrm{Sg}$-have leg

I have leg'

\section{Topicalization}

Syntactically, the structure of the construction $2 \mathrm{a}-\mathrm{b}$ are correct, but there is a conceptual restriction that body parts are gifted not something to be possessed. It is also proved by the following construction which people can say (3a), bu t not (b).

3) a Ume lena au Pmuir-ka

House that $1 \mathrm{Sg}$ possession-1 $\mathrm{Sg}$

'The house is my possession'

b **Hae le i au Pmui?-ka

Leg this $1 \mathrm{Sg}$ have-1 $\mathrm{Sg}$

'This leg is my possession'

It is clearly shown that ume 'house' in data (3a) is a possession, but not for hae 'leg' in data (b). The word : mui: 'possession' is always modified by the enclitic to mark inalienability or to indicate that there is a strong emotion or mental relationship between possessor and possession. The marking on possession will change based on its possessor. This verbless clause construction as in data (3) is also called topicalization strategy following (Aikhenvald, 2013). The structure of the clause of the above data can appear with the following construction:
4). a Aи Pmui?-ka es ume lena
$1 \mathrm{Sg}$ possession is house LOC that
'My possession is that house'
b Au Pmui?-ka es lena
$1 \mathrm{Sg}$ possession-1Sg LOC that
'My possession is that'
c. Au Pmui?-ka 
1Sg possession-1Sg
'My possession'
d. Ume na au
house that $1 \mathrm{Sg}$
'That house is mine'
In data (4a) above, au: mui: $-k a$ "my possession" is the subject of the clause and become the topic of the clause. Comparing the construction (3a) and (4a), it can be concluded that topicalization strategy in in Uab Meto is by looking at the subject of the clause. In (4b), the possession ume "house" is absent but the construction is grammatical and not changing the meaning. Construction in data (4c) and (4d) are presented in order to prove that construction (3a) and (4a) are applying the topicalization strategy to expressing possessive construction.

There is another construction similar to topicalization as in (5).

\section{5) Au bie ha}

$1 \mathrm{Sg}$ cow four

I have four cows' (LIT. my cows is four)

Construction above can be analyzed as a juxtaposed construction, which is formed by two noun phrases, au (possessor NP) + bie ha (possession NP). It can also as a copular clause, in which au bie is copula subject and ha is copula complement. These two construction, juxtaposition and copular clause are acceptable in Uab Meto for expressing the possession. The interpretation is depend on the topic of the discourse.

\section{Verbal prefix ma-}

Predicative possession construction in Uab Meto can appear in form of prefix $m a-$ attached to possession as a pertentive marker. This prefix is a verbal prefix because it carries a verbal meaning, that is have/has. The use of prefix $m a$ - to possessive construction in Uab Meto can be seen clearly bellow.

6) a. Na nani ma-ume

ART NAME POSS-house

'Nani has hause'

b. atoni na ma-kana

people that POSS-name

'That people is famous'

The possessive prefix is having the same function as the predicative possession mui. So, ma-ume in data (6a) means has house and $m a$ kana in (6b) means has name. There is a difference in the use of prefix $m a$ - for both maume and makana, that is maume is showing the ownership and makana is showing the whole part relationship.

Another thing to be noted is that the use of prefix $m a$ - in ma-kana means famous which as a literal meaning 'has name'. It means that the use of prefix $m a$ - to the whole part relationship including body part possession such as maluke 'has ear', mafefa 'has mouth' convey idiomatic meaning.

\section{Attributive Possession}

Attributive possession in Uab Meto is expressed in form of noun phrase by two different ways, namely juxtaposition and clitic.

\section{Juxtaposed possession}

Juxtaposed constructions involve two NPs, namely a possessor NP and a possessed NP. The possessor in juxtaposed constructions can be a noun or pronoun. Uab Meto allows all pronouns to mark the attributive possessive relation. There is no morphological marking that mark this possessive relationship but determined by word order. The order of this construction is always possessor + possessed. Here are the examples.

6) a. Ho fafi

$$
\begin{aligned}
& \text { 2SG pig } \\
& \text { 'your pig' }
\end{aligned}
$$

b. Na Lukas ume

ART NAME house

'Lukas' house'

c. Au tata fe

$1 \mathrm{Sg}$ older brother wife

'my older brother's wife'

There are two ways to distinguish whether the pronouns as in data above are possessive or subject is by looking at them syntactically and phonological. Syntactically is by lexical order of the possessive phrase, which is possessor-possession. In this type, there is no morphological marking on both possessor and possessed. Phonologically is by the stress on the utterance, for example, ho fafi have three different stresses, namely stress on $f a f i$, while ho is weak to mean 'your pig', second is stress on ho to mean 'you, pig', and third is on both ho and fafi to mean 'yours, pig'.

\section{Clitic}

Attributive possession in Uab Meto can be indicated by the presence of enclitic that attached to the possessed noun as seen in the following data. 
7) a. na Jemi Pnaka-n

ART N AME head-3Sg

'Jemi's head'

b. au hae-k

\section{$1 \mathrm{Sg}$ leg- $1 \mathrm{Sg}$}

'my leg'

The existence of enclitics $-n$ in Pnaka- $n$ 'his head' and $-k$ in hae- $k$ 'my leg' to show the agreement with the possessors. That is, marking on the possession will change following the possessor as shown in the table.

Table 1

Marking on the possession

\begin{tabular}{|c|c|c|c|c|}
\hline \multirow{2}{*}{\multicolumn{2}{|c|}{ Pronoun }} & \multirow[t]{2}{*}{ Free } & \multicolumn{2}{|c|}{ Clitic } \\
\hline & & & Asyllabic & Syllabic \\
\hline \multirow{3}{*}{1} & $\mathrm{~S}$ & $A u$ & $-k$ & $-k a / u$ \\
\hline & P.i & Hit & $-k$ & - \\
\hline & P.e & $\mathrm{Hai}$ & $-m$ & - \\
\hline \multirow{2}{*}{2} & $\mathrm{~S}$ & Ho & $-m$ & $-m a / u$ \\
\hline & $\mathrm{P}$ & $H i$ & $-m$ & - \\
\hline \multirow{2}{*}{3} & $\mathrm{~S}$ & In & $-n$ & $-n a$ \\
\hline & $\mathrm{P}$ & $\operatorname{Sin}$ & $-k$ & - \\
\hline
\end{tabular}

The clitic type of possession as presented above is only indicating the inalienable possession such as body part. In other words, clitic in possession in is obligatory for inalienable possession in Uab Meto.

Looking at this construction, it is similar to the juxtaposed possession, but it differs in that pertensive clitic on the possession. Data bellow will give more explanation.

8) a. ho feto lasi na-leu? neka-k

$2 \mathrm{Sg}$ sister case 3Sg-broke heart-1P.i

'your sister's case broke our heart'

b. Au iti neu luke-n

\section{Sg pinch PREP ear-3Sg.POSS}

'I pinched him/her on his/her ear'

The pertensive $-k$ in nekak is the $1 \mathrm{P} . \mathrm{i}$ clitic. So, without free pronoun as the possessor, a speaker will understand that it is a possessive noun phrase. The possessive NP nekak 'our heart' is the same as luken 'his/her ear' in data (8b).

\section{CONCLUSION}

Uab Meto has two types of possessive construction; they are predicative and attributive possession. Predicative possession is realized by mui? 'have/has' construction, topicalization strategy, juxtaposed construction, and verbal prefix $m a$ - which means have/ has.

Relating to the morphological marking on the possessive construction in Uab Meto, there are two ways of marking that is by juxtaposition construction and on possession which can be achieved with the 'pertensive' marker.

The discussion in this paper only covers the morphological aspect of possessive construction. Therefore, it needs further investigation to discover its semantics aspect, following (Payne, 1997) to make clear distinction of alienable and inalienable possession and also (Dixon, 2010) to classify the wide range relationship of possession in Uab Meto.

\section{REFERENCES}

Aikhenvald, A. Y. \& Dixon, R, M, W. (2013). Possession and Ownership: A Cross Linguistic Perspective. New York: Oxford University Press.

Dixon, R. M. W. (2005). A Semantic Approach to English Grammar (Second Edi). New York: Oxford University Press.

Dixon, R. M. W. (2010). Basic Linguistic Theory: Grammatical Topics (Volume 2). New York: Cambridge University Press.

Haspelmath, M. (2008). Alienable vs. Inalienable possessive constructions in Syntactic Universals and Usage Frequency. Leipzig Spring School on Linguistic Diversity.

Heine, B. (1997). Possession: Cognitive Sources, Forces, and Grammaticization. Cambridge: Cambridge University Press.

Lødrup, H. (2011). Norwegian Possessive Pronouns: Phrases, Words Or Suffixes? In Proceedings of the LFG11 Conference Miriam Butt and Tracy Holloway King (Editors). CSLI Publications. Retrieved from http://csli-publications.stanford.edu/

McDonnell, B. J. (2008). Possessive Constructions in Ende: A Language of Eastern Indonesia. Studies in Philippine Languages and Cultures, 18, 108-118.

Moeljadi, D. (2011). Possessive Verbal Predicate Constructions in Indonesian. Tokyo University Linguistic Paper. 31, 117-133.

Ngongo, M. (2014). Possession in Text of Waijewa Language. Vision Journal: A Biannual Publication on the Research of Language, Literature, Culture and Education, 1(1), 39- 
46.

Nishiyama, K. (2009). Possessive Constructions in Lamaholot. Journal of Linguistic. 47(2), 381405 .

Payne, T. E. (1997). Describing Morphosyntax. New York: Cambridge University Press.
Tallerman, M. (2011). Understanding Syntax (Third Edit). London: Hodder Publication.

Wang, Y., \& Xu, J. (2013). A systemic typology of existential and possessive constructions. Functions of Language, 20(1), 1-30. https:// doi.org/10.1075/fol.20.1.01wan 